bill all funding for 1975, in return for cuts across the board for the three years encompassed by the bill. In any case, the bill contains only authorizations requests, and the appropriations committees must agree to the expenditures if the bill is passed-it is very unlikely that they would give their blessing to the total amount.

What are the prospects that the bill will be passed by the House of Representatives before Congress disperses for the November elections? Much depends on how quickly it is dealt with in committee and on how long Congress stays in session. But the prospects are not good. For one thing, John W. Davis, chairman of the key subcommittee on Science, Research and Development, has been occupied with a tough primary election, and so the bill has languished in his committee since he introduced it at the beginning of July. And for another, the House of Representatives is already facing a backlog of business to be dealt with before it can break up, so it would be difficult to fit the bill into the schedule.

One aspect in its favour, however, is that it is likely to be cited by Senator McGovern as a vehicle for offsetting the effects of his proposed defence cuts, and there will thus be strong pressure on Democrats in the House to deal with it quickly. But, alternatively, the White House will want to keep it bottled up in committee, and is likely to put pressure on Republican members to stall it for as long as possible. In any case, if the bill is not passed this year, it will almost certainly pop up again next session.

\section{AIR POLLUTION}

\section{Clean Air in Jeopardy}

by our Washington Correspondent

ONE of the chief provisions of the Clean Air Act may be jeopardized by an acute shortage of low sulphur fuels in the United States. According to a study commissioned by the Environmental Protection Agency, supplies of low sulphur coal and oil will be grossly inadequate for each state to meet the primary air quality standards - which are designed to protect health-by 1975 . Clean coal, particularly in the midwest, will be the biggest problem, but there is also expected to be a severe shortage of oil.

The standards, which were set by the EPA under the terms of the Clean Air Act, were designed to reduce sulphur emissions by 50 per cent between 1971 and 1975, and each state must detail how it intends to meet the standard. So far, the plans of 13 states have been approved by the EPA, and the others are under discussion.
The study, which was carried out by the Mitre Corporation of Bedford, Mass., consisted of adding up the quantities of low sulphur fuel required by each state in its plan for meeting the standards, and attempting to match it with the projected supply. The results are that in 1975,592 million tons of low sulphur coal will be required, but only 268 million tons will be available. Similarly, 1,439 million barrels of lowsulphur oil will be required to meet the standards, but only 1,048 million will be available. The only fuel for which no acute shortage is predicted is natural gas.

Although there have been suspicions about the availability of low sulphur fuels in the US for some time, it was only about two weeks before the states were required to submit their implementation plans to the EPA that the Mitre Corporation's preliminary report exposed the gravity of the situation. That was in May, and the EPA did not make the study public until last week, after it had been leaked to Congressman Les Aspin of Wisconsin.

The agency clearly has a tough problem on its hands, for either it must relax the standards, at least in some areas, or find new sources of low sulphur fuels. The Mitre study examined essentially two approaches that the agency might take, one of which involves importing low sulphur oil to fill the gap and the other entails the modification of implementation plans for a few states, chiefly those in the midwest.

The first approach would result in imports of some 740 million barrels of oil a year, a quantity which would wreck the oil import quota system and disturb the balance of payments to the tune of $\$ 3,000$ million. The second approach would involve altering the implementation plans for those areas which will have little difficulty in meeting the standards, and use the available low sulphur fuels in the areas where air quality is worst. This approach, which the report calls "the least costly and lowest impact strategy", may, however, increase sulphur oxide pollution in some parts of the country.

The EPA's only public discussion of the study is in the Federal Register of May 31, 1972, some two weeks after the Mitre study was delivered to the agency. The EPA submission points out that "plans in the aggregate cannot be achieved by 1975 despite the best efforts of government and the private sector", and suggests that states should continue to develop their implementation plans on the assumption that the standards can be met. In the meantime EPA will be completing its studies of the aggregate situation and will suggest necessary changes to the states, and likewise modify federally promulgated $\mathrm{SO}_{\mathrm{x}}$ regulations for achievement of the secondary standards where appropriate. (The secondary standards are more stringent than the primary standards, and come into force in about 1977,) The EPA discussion concludes that "highest priority must be given to achieving the primary standards (health related) by the statutory deadiine".

\section{HEALTH RESEARCH \\ NIH Funds Vetoed}

by our Washington Correspondent THE financial bonanza that Congress had budgeted for the National Institutes of Health for the 1973 fiscal year has been vetoed by President Nixon. Living up to his frequently repeated promise to avert tax increases, Nixon has refused to sign the appropriation bill for the departments of Labor and Health, Education and Welfare -- which includes the budget for NIH-because it added up to some $\$ 1,800$ million more than he had requested.

The veto could have been overridden by Congress if two-thirds of the members voted to do so, but supporters of the bill in the House of Representatives could muster only 203 votes against 171. The appropriations committees in the House and Senate must now go back to the drawing boards and come up with another bill that is closer to President Nixon's budget request. Congress had wanted to give the research institutes of NIH $\$ 1,794$ million-over $\$ 300$ million more than they received last year, and about $\$ 200$ million more than the Administration asked for.

In his message explaining his reasons for vetoing the bill, President Nixon called it "a perfect example of that kind of reckless Federal spending that just cannot be done without more taxes or more inflation, both of which I am determined to avoid" - holding down taxes is a bigger vote catcher than increasing expenditure on welfare. And he also warned Congress against sending the bill back with only token cuts. Such action, he said, would not satisfy his objections to the bill, and what he wants is a measure which involves total expenditures no greater than he originally requested. In the meantime, NIH must be content with a budget for 1973 which continues expenditures at the same level as 1972 (the 1973 fiscal year started on July 1). New programmes must therefore await passage of a more acceptable appropriations bill. 